\title{
PENINGKATAN KOMPETENSI GURU DENGAN PENGKOLABORASIAN MEDIA KONVENSIONAL DAN MODERN APLIKASI TAJWID DI BDK ACEH
}

\author{
Nurdin \\ Balai Pendidikan dan Pelatihan Keagamaan Kementerian Agama, Provinsi Aceh \\ e-mail: nurdyn43@gmail.com
}

\begin{abstract}
The problems in today's learning are the low competence and the lack of the ability of teachers to use media in learning and collaborating with other media. In the process of learning the Qur'an Hadith, teachers are still dominant using conventional / traditional media such as: markers, blackboards, textbooks, papers and teachers only read while students imitate so that it leads to low student learning outcomes towards mastery of recitation. This study is intended to determine the competence of teachers in utilizing learning media and collaborating between conventional / traditional media with modern applications of recitation in Balai Diklat. This study uses a qualitative approach / method with descriptive type. The technique of data collection is by interview, observation and documentation, while the data analysis techniques are carried out in the phase of data reduction, data presentation and conclusion drawing. The results showed that, almost all the teachers in the Al-Qur'an hadith learning material Tajwid Sciences still used conventional media. Second, teacher competency in the Education and Training Center in learning is more improved and the learning process is more interesting with the collaboration of conventional media and modern media applications of recitation science. Conclusion: Nowadays in the learning process the teacher is still dominant using conventional conventional learning media compared to modern media, the learning process is more interesting and the results are even more increased if the teacher collaborates conventional media with modern learning media, namely the Tajwid science application.
\end{abstract}

Keywords: Teacher competencies, conventional media, modern media, tajwid science application. 


\section{PENDAHULUAN}

Guru memegang peran penting dalam menyukseskan keberhasilan pendidikan peserta didik. Maka salah satu upaya meningkatkan keberhasilan mereka adalah guru harus memiliki berbagai kompetensi dibidangnnya, yang sering disebut dengan kompetensi professional. Kompetensi profesional merupakan penguasaan materi pembelajaran secara luas dan mendalam, yang mencakup penguasaan materi kurikulum mata pelajaran di sekolah dan substansi keilmuan yang menaungi materinya, serta penguasaan terhadap stuktur, metodologi, strategi dan media dalam pembelajaran. Jejen Musfah (2015: 27) hakikat kompetensi adalah kekuatan mental dan fisik untuk melakukan tugas atau keterampilan yang dipelajari melalui latihan dan praktek. Dari hal ini maka suatu kompetensi dapat diperoleh melalui pelatihan dan pendidikan.

Standar Kualifikasi Akademik dan Kompetensi Guru diatur dalam Peraturan Menteri Pendidikan Nasional (Permendiknas) Nomor 16 Tahun 2017. Kompetensi yang harus dikuasai dan diterapkan oleh guru profesional dalam membelajarkan siswa di kelas menurut Sudjana dalam (Abdul Hadis \& Nurhayati, 2012: 19-20), ialah mencakup: Menguasai bahan atau materi pelajaran, mengelolaprogram belajar mengajar, mengelola kelas, menggunakan media atau sumber belajar, menguasai landasan pendidikan, mengelola interaksi belajarmengajar, menilai prestasi belajar siswa.

Guru sebagai pengelola pembelajaran dituntut untuk dapat kompetensi dalam melakukan perencanaan, pelaksanaan, serta evaluasi pembelajaran. Kegiatan pembelajaran merupakan proses komunikasi. Dalam hal ini, Noeng Muhadjir menyebutkan sebagaimana dikutip oleh Siswoyo (2013: 117), bahwa prasyarat seseorang bisa sebagai pendidik apabila seseorang tersebut: (1) memiliki pengetahuan lebih, (2) mengimplisitkan nilai dalam pengetahuan itu dan (3) bersedia menularkan pengetahuan beserta nilainya kepada orang lain.

Pesatnya teknologi dan informasi yang telah merambah ke semua sektor kehidupan masyarakat menuntut seorang guru memiliki kemampuan untuk menguasai teknologi tersebut. Di era yang serba modern tersebut, di mana belajar itu mudah dilakukan dengan berbagai media yang ada, membuat guru sebagai pendidik harus bisa memberikan pelayanan pendidikan kepada mereka sesuai kebutuhan dan jamannya. Dengan begitu guru harus memiliki kemampuan mengelola pembelajaran, kemampuan memberikan teladan yang baik, kemampuan menjadi guru yang profesioanl, dan kemampuan untuk berkomunikasi dan berinteraksi. Menurutnya (Cecep Kustandi \& Bambang Sutjipto, 2011: 7) bahwa media sebagai alat bantu mengajar, berkembang sedemikian pesatnya sesuai dengan kemajuan teknologi. ragam dan jenis media pun cukup banyak sehingga dapat dimanfaatkan sesuai dengan kondisi, waktu, keuangan, maupun materi yang akan disampaikan. media memiliki kontribusi dalam meningkatkan mutu dan kualitas pembelajaran. kehadiran media tidak saja membantu pengajar dalam menyampaikan materi ajarnya, tetapi memberikan nilai tambah pada kegiatan pembelajaran.

Namun pada kenyataan di lapangan menunjukkan bahwa, tidak semua guru yang mengajar Al-Qur'an Hadis memiliki kompetensi dalam menerapkan strategi dan metode pembelajaran yang bervariasi dan menarik, sehingga membuat peserta didiknya bosan dalam mengikuti pembelajaran Al-Qur'an Hadis. Karena 
salah mata pelajaran yang masih diminati oleh siswa saat ini adalah materi pelajaran Al-Qur'an Hadis. Padahal Al-Qur'an Hadis merupakan salah satu mata pelajaran, yang mau tidak mau peserta didik harus mempelajari dan menguasainya.

Kondisi lain yang terjadi di madrasah atau sekolah saat ini adalah sumber belajar dan media pembelajaran yang digunakan guru dalam mengajarkan AlQur'an Hadis sangat minim yakni masih menggunakan media konvensional atau madia manual yakni berupa cara guru menjelaskan dengan metode ceramah, media yang digunakan adalah papan tulis, kertas, spidol, buku paket tanpa menggunakan media modern yang dapat mengikat hati peserta didiknya sehingga dapat dikatakan bahwa guru masih memiliki keterbatasan dalam menjalankan perannya, sehingga perlu adanya sumber belajar lain dan didukung dengan menggunakan media pembelajaran yang lebih modern. Sumber belajar yang digunakan selama ini adalah buku cetak dan belum ada media modern lainnya yang digunakan untuk menunjang pembelajaran kearah yang lebih maju.

Hasil observasi dan wawancara penulis yang pernah dilakukan kepada beberapa guru atau peserta diklat Al-Qur'an Hadis Tingkat Aliyah dan kepada Peserta Diklat Penyuluh Agama Islam Non PNS di Balai Diklat Keagamaan Aceh menunjuki bahwa kebanyakan guru dalam mengajarkan Al-Qur'an Hadis kepada peserta didiknya masih menggunakan cara-cara yang manual atau cara-cara yang lama, seperti saat mengajarkan materi tersebut hanya mengandalkan spidol, papan tulis, buku Paket, peniruan suara guru dan metode ceramah sehingga membuat peserta didik mengantuk sehingga menimbulkan kebosanan mereka dalam belajar Al-Qur'an.

Kondisi tersebut sangatlah disayangkan dari seorang guru mengingat teknologi saat ini yang semakin hari semakin canggih yang menuntut mereka harus meng-update terus informasinya dan meningkatkan kompetensinya dalam bidang penerapan berbagai media dalam proses pembelajaran, tanpa sepenuhnya meninggalkan media konvensional atau manual.

Berdasarkan kondisi tersebut hendaknya guru yang mengajarkan Al-Qur'an Hadis khusunya materi Ilmu Tajwid harus mengubah pola, strategi, metode dan media yang lebih modern atau digital dalam pembelajaran. Beberapa solusi yang perlu diterapkan oleh guru saat melaksanakan proses pembelajaran Al-Qur'an Hadis yaitu: hendaknya guru perlu memvariasikan berbagai metode dalam pembelajaran. Dan hal yang sangat penting lagi bahwa, berhubung materi Ilmu Tajwid merupakan ilmu yang tergolong sulit dipahami oleh peserta didik, hendaknya guru perlu mengkolaborasikan berbagai media dalam pembelajaran. Pengkolaborasian media yang penulis maksud adalah memadukan antara media konvensional/manual dengan media modern/digital. Salah satu media modern atau digital dalam pembelajajaran Al-Qur'an hadis adalah aplikasi Ilmu Tajwid.

Pengkolaborasioan media konvensional dengan modern digital Ilmu Tajwid dapat membantu peserta didik untuk mempelajari materi yang kompleks tanpa terikat waktu. Selain itu, penyajian materi dengan adanya interaksi peserta didik dengan pengkoraborasian tersebut dapat meningkatkan motivasi siswa untuk belajar ilmu Tajwid. Hal ini juga berkaitan dengan karakteristik peserta didik tingkat Aliyah yang sudah mampu untuk berfikir logis dan abstrak dan peserta 
didik Tingkat Taman Kanak-Kanak di Desa yang belum mampu berfikir logis sehingga sangat tepat kalau pengkolaborasian media pembelajaran tersebut.

Pengkolaborasian media konvensional dengan media modern aplikasi digital ilmu tajwid yang penulis terapkan saat melaksanakan pembelajaran Al-Qur'an bagi peserta diklat guru Madrasah Aliyah dan Penyuluh Agama Islam Non PNS di Balai Diklat Keagamaan Aceh memperlihatkan semangat belajar mereka semakin tinggi dan menarik sehingga hasil belajar peserta diklatpun semakin meningkat. Berdasarkan latar belakang di atas peneliti sangat tertarik untuk melakukan penelitian ini dengan menerapkan Pengkolaborasian media konvensional dengan media modern aplikasi digital Ilmu Tajwid.

\section{METODE PENELITIAN}

Metode yang digunakan dalam penelitian ini adalah studi lapangan (field research) dengan kolaborasi studi kajian pustaka (library research). Dengan sifat penelitian diskriptis-analitis. Teknik pengumpulan datanya adalah dokumentasi, observasi dan wawancara, selanjutnya setelah data yang dibutuhkan terkumpul dianalisis dengan metode deduktif-induktif.

Penelitian ini dilaksanakan di Balai Pendidikan dan Pelatihan Keagamaan Aceh. Mekanisme/langkah dalam penelitian dibagi dalam tiga tahapan, yaitu 1) tahapan persiapan penelitian meliputi studi pendahuluan, melakukan observasi dan wawancara dengan beberapa responden; 2) tahapan pelaksanaan penelitian meliputi wawancara langsung dengan responden terkait dengan kompetensi guru atau peserta diklat dalam menggunakan media pembelajaran saat melaksanakan tugas masalah ilmu tajwid; dan 3) penarikan kesimpulan berdasarkan rumusan masalah dan untuk menjawab tujuan penelitian.

Subyek dalam penelitian ini adalah seluruh guru Al-Qur'an Hadis Tingkat Aliyah 30 orang dan peserta diklat Penyuluh Agama Islam Non PNS di Balai Diklat Aceh yang berjumlah 30 orang, dengan sampel 5 orang guru Al-Qur'an Hadis dan 5 orang Penyuluh Agama Islam Non PNS sehingga total sampelnya 10 orang. Ke-10 responden tersebut dilakukan wawancara dan observasi terkait dengan kompetensi mereka menggunakan media pembelajaran saat melakukan praktek pembahasan ilmu tajwid.

\section{HASIL PENELITIAN DAN PEMBAHASAN HASIL PENELITIAN}

Analisis data hasil penelitian ini dilakukan dengan mengolah semua informasi yang diperoleh dari hasil observasi dan wawancara dan selanjutnya dideskripsikan berdasarkan permasalahan masing-masing. Berdasarkan hasil analisis data, kompetensi guru dalam mengkolaborasikan media konvensional manual dan media modern digital Ilmu Tajwid dalam pembelajaran Al-Qur'an Hadis di Balai Diklat Keagamaan Provinsi Aceh dapat dideskripsikan sebagai berikut:

\section{Kompetensi Guru/ Penyuluh Dalam Menggunakan Media Pembelajaran Ilmu Tajwid}

Materi Al-Qur'an hadis merupakan materi yang mudah untuk dipelajari dan diajarkan bagi peserta didik dan kadang-kadang materi Al-Qur'an juga menjadi materi yang rumit untuk dimengerti dan diajarkan oleh pendidik kepada peserta 
didiknya khususnya materi ilmu tajwid. Ilmu tajwid menjadi salah satu topik bahasan yang dipelajari dan diajarkan kepada peserta diklat Al-Qur'an Hadis dan Penyuluh Agama Islam Non PNS. Mata Diklat Al-Qur'an hadis termasuk didalamnya ada materi ilmu tajwid, karena yang dipelajari adalah mengenai hukum iomu tajwid. Berdasarkan kurikulum Pusdiklat Kementerian Agama Republik Indonesia di bawah Badan Penelitian dan Pengembangan, standar kompetensi dan kompetensi dasar yang diharapkan dalam topik bahasan mawaris adalah sebagai dalam tabel berikut:

Tabel 1

Topik Bahasan Ilmu Ilmu Tajwid

\begin{tabular}{ll}
\hline Standar kompetensi & Kompetensi dasar: \\
Memahami hukum Ilmu & Menjelaskan ketentuan-ketentuan hukum \\
Tajwid & Ilmu Tajwid \\
& Menjelaskan Hukum Nun Sukun/Tanwin \\
& Menjelaskan Huruf Syamsiyah Dan \\
& Qamariyah \\
& Menjelaskan ketentuan hukum mad, Waqaf \\
& dan Ibtida' \\
& Menjelaskan ketentuan Makharijul Huruf \\
& Menjelaskan \\
\hline
\end{tabular}

Dari standar kompetensi dan kompetensi dasar tersebut, tedapat materi yang harus dikuasai betul-berul oleh peserta diklat dan dapat diajarkannya ke peserta didik. Materi tersebut yaitu: a. hukum mad, b. makharijul huruf, c. Masalah mad dan waqaf. Pengembangan media pembelajaran dalam penelitian ini disesuaikan dengan kurikulum yang berlaku, sebagaimana telah diungkapkan dalam standar kompetensi, kompetensi dasar, serta materi yang harus dikuasai oleh guru.

Materi subtansi Al-Qur'an hadis yang di dalamnya mencakup ilmu tajwid ini secara keseluruhan diampu dan diajarkan oleh narasumber/widyaiswara Balai Diklat Keagamaan Aceh. Penulis sendiri sebagai pemateri terhadap peserta diklat tentunya memantau segala aktifitas pembelajaran dengan peserta diklat. Dalam proses pembelajaran materi ini, yang jumlah jam pelajarannya 9 jam, tentunya ada yang namanya materi tentang teori pembelajaran ilmu tajwid. Materi teori ini, penulis menjelaskannya dengan metode ceramah, diskusi kelas, Tanya jawab dan curah pikiran. Di samping itu juga tidak lupa bahwa dalam proses pembelajaran tersebut dengan menggunakan media pembelajaran baik sifatnya media konvensional/manual dan media modern. Setelah penulis menyampaikan teori sekitar 3 jam pelajaran, maka kegiatan pembelajaran berikunya dilanjutkan dengan tugas kelompok.

Dalam tugas kelompok tersebut, penulis memberikan tugas kepada peserta diklat/guru berupa soal-soal. Tujuan pemberian soal kepada peserta diklat adalah penulis ingin mengetahui sejauh mana kompetensi dan kemahiran peserta menggunakan media pembelajaran. Hasil observasi penulis terhadap kegiatan peserta dalam peserta dalam proses diskusi, ditemukan beberapa media 
pembelajaran manual/ konvensial yang masih digunakan oleh peserta diklat saat mengerjakan tugasnya, sebagaimana terlampir pada tabel berikut:

Tabel 2

Media yang digunakan peserta diklat/guru dalam kegiatan pembelajaran Al-Qur'an Hadis Ilmu Tajwid

\begin{tabular}{lll}
\hline No & Media Konvensional & $\begin{array}{l}\text { Media } \\
\text { Modern/ digital }\end{array}$ \\
1 & Pulpen & Tidak ada \\
2 & Kertas A4 & Tidak ada \\
3 & Modul & Tidak ada \\
4 & Papan plik cart & Tidak ada \\
5 & Buku Tulis & Tidak ada \\
\hline
\end{tabular}

Berdasarkan tabel di atas, menunjukkan bahwa dalam pelaksanaan pembelajaran Al-Qur'an Hadis, umumnya peserta masih menggunakan media pembelajaran manual, tak seorangpun dari peserta diklat menggunakan media modern/manual sehingga dapat memudahkan mereka dalam menyelesaikan tugas kelompoknya.

Dari data tersebut dapat dikatakan bahwa semua responden belum bisa menggunakan media sesuai dengan materi yang mereka pelajaran. Padahal penggunaan media yang tepat dan sesuai dengan perkembangan teknologi seperti modern akan sangat membantu meningkatkan motivasi dan hasil belajar siswa nantinya di sekolah. Akan tetapi menurut asumsi penulis bahwa kemungkinan masih ada guru yang belum bisa menggunakan media pembelajaran modern dengan baik. Masalah tersebut perlu diketahui untuk dijadikan evaluasi agar keunggulan media pembelajaran modern dapat dimanfaatkan secara maksimal.

Oleh karena itu, guru dituntut harus bisa menggunakan serta memanfaatkan teknologi informasi dan komunikasi sebagai media dalam prosespembelajaran sehari-hari. Rusyan (2014: 27) mengatakan, untuk memiliki kemampuan dan keahlian, para guru dituntut meningkatkan pengetahuan, memakaidan menguasai teknologi, baik itu komputer maupun alat-alat teknologi lainnya yang dapat digunakan dalam pembelajaran.

Berdasarkan hasil observasi dan wawancara dengan guru, di Balai Diklat Keagamaan Aceh sudah mempunyai fasilitas komputer, infokus, layanan internet (Wifi), serta beberapa notebook/ netbook baik milik pribadi peserta diklat berupa hp andoroid maupun milik balai Diklat, tetapi sebagian guru masih menggunakan media konvensional dalam pelaksanaan pembelajaran, padahal fasilitas untuk pemanfaatan media pembelajaran berbasis Modern di Balai Diklat Keagamaan Aceh sudah cukup memadai.

Untuk mengetahui media apa saja yang digunakan oleh guru saat berlangsungnya kegiatan diskusi kelompk, maka peneliti melakukan wawancara dengan beberapa orang peserta diklat. Dalam hal ini, salah seorang peserta mengatakan bahwa: Media yang kami gunakan hanya papan tulis, buku, kertas, pulpen dan spidol, karena media lain untuk mengajar ilmu tajwid ini belum kami 
kenal apalagi menggunakannya. Namun, penulis berasumsi bahwa melalui menghitung secara manual serta menulisnya di papan tulis dan menggunakan kitab rujukan itu saja sudah memadai bagi kami. Selain itu, penulis juga telah mengamati langsung di lokasi penelitian bahwa ketika pembelajaran Al-Qur'an hadis materi ilmu mawarsi berlangsung di Balai Diklat Keagamaan Aceh, bahwa media pembelajaran yang digunakan guru saat menyelesaikan tugas kelompok masih berupa pulpen, spidol, modul, papan plic cart dan buku tulis.

Berdasarkan deskripsi wawancara tersebut dengan beberapa orang peserta diklat dan hasil observasi dalam proses pembelajaran, dapat disimpulkan bahwa media pembelajaran yang digunakan oleh para peserta diklat masih berbentuk media tradisional, yaitu buku paket siswa, buku pegangan guru, papan tulis, spidol, pulpen dan penghapus, belum menggunakan media digital modern.

\section{Kompetensi peserta diklat/guru menggunakan fasilitas modern yang tersedia sebagai media pembelajaran Al-Qur'an}

Selama pelaksanaan proses pembelajaran di kelas, terutama saat berlangsungnya diskusi tugas kelompok, penulis melakukan wawancara dan observasi terkait dengan kemampuaan peserta diklat menggunakan media modern dalam menyelesaikan soal ilmu tajwid. Hasil observasi tersebut penulis tuangkan dalam tabel berikut:

Tabel 3

Pernah tidaknya guru menggunakan media modern (Aplikasi Digital) dalam Pembelajaran Al-Qur'an Ilmu Tajwid

\begin{tabular}{lccc}
\hline No & & \multicolumn{2}{c}{ Responden } \\
& Sering & Jarang & Tidak Pernah \\
\hline 1 & 2 & 3 & 5 \\
2 & - & - & - \\
\hline
\end{tabular}

Berdasarkan tabel di atas yang di dasari dengan hasil observasi di masing-masing kelompok responden, didapatkan bahwa 5 orang responden yaitu guru yang berinisial $\mathrm{MH}, \mathrm{ZN}, \mathrm{AH}, \mathrm{AB}, \mathrm{MJ}$ sama sekali tidak pernah menggunakan media digital, dan 3 orang responden lain yaitu KM, MT, TB baru mengenal tetapi belum pernah menggunakan media modern dengan baik dan benar, sedangkan dua orang responden lainnya yaitu SK dan $\mathrm{MH}$ sudah pernah menggunakan media modern sebagai media pembelajaran dalam mengajar Al-Qur'an terutama Ilmu tajwid.

\section{Kesesuaian media yang digunakan guru dengan tujuan pembelajaran}

Berdasarkan hasil wawancara dengan 10 responden semuanya menjawab belum sesuai dengan tujuan pembelajaran ilmu tajwid ini, seperti kata salah satu responden yang mengatakan, "Menurut saya semua media yang kami gunakan dalam pembelajaran ilmu tajwid ini belum sesuai dengan tujuan pembelajaran, hal ini menurut kami bahwa rata-rata kami dalam menyelesaikan tugas kelompok tidak tepat waktu menyelasaikannya, hal ini mengingat bahwa kemampuan kami dalam menggunakan media modern sangat berkurang".

Selanjutnya berdasarkan hasil observasi di masing-masing kelompok responden, didapatkan bahwa 6 orang guru yang berinisial AH, AB, MJ, MH, ZN dan KM belum sesuai dalam menggunakan media dengan tujuan pembelajaran ilmu 
Tajwid. Sedangkan tiga responden lainnya yaitu MT, TB dan dan SK hampir sesuai dalam menggunakan media sesuai dengan tujuan pembelajaran dan hanya satu orang responden yaitu Bapak MH sudah menggunakan media digital modern.

Berdasarkan hasil observasi dan wawancara dengan beberapa responden terkait dengan kompetensi guru menggunakan media pembelajaran dalam pembelajaran Al-Qur'an hadis termyata terjawab sudah bahwa umumnya guru masih menggunakan media manual baik saat melaksanakan proses mengajar dengan anak didik di sekolah maupun saat berlangsungnya kegiatan diskusi di kelas, hal ini terindikasi bahwa kompetensi guru Al-Qur'an Hadis dan Penyuluh Non PNS dalam menggunakan media pembelajaran masih kurang.

\section{Ketepatan media Digital Modern yang digunakan dengan materi pembelaja ran Al-Qur'an Hadis Materi Ilmu Tajwid}

Hasil observasi di masing-masing kelompok diskusi, didapatkan bahwa dua orang guru yang berinisial SK, MH, KM, MT, TB, ZN, AH, AB, dan MJ belum tepat dalam menggunakan media sesuai dengan materi pembelajaran ilmu mawaris. Selain kesembilan responden tersebut terdapat satu responden lainnya yaitu HL sudah tepat dalam menyesuaikan media sesuai dengan materi pembelajaran ALQur'an hadis terutama menyangkut materi ilmu tajwid.

\section{Upaya guru dalam mengkolaborasikan media Konvensional/manual dan media modern Aplikasi Ilmu Tajwid pada pembelajaja ran Al-Qur'an Hadis}

Kemampuan guru dalam mengkolaborasikan berbagai media dalam pembelajaran sangat penting, lebih-lebih di zaman era milenial ini. Di zaman modern seperti sekarang ini, menuntut penyesuaian dalam segala hal supaya hasil yang di harapkan dari tindakan yang di lakukan sesuai dengan tuntutan zaman. Termasuk juga dalam proses pembelajaran. Media pembelajaran ini bermacammacam dari yang klasik sampai yang modern. Supaya mampu menggunakan media pembelajaran ini, sebaiknya seorang guru mampu memadukan secara baik penggunaan media pembelajaran klasik dan modern. Salah satu hal yang sangat penting bagi guru dalam menggunakan media pembelajaran adalah perlunya guru mengkolaborasikan antara media konvensional manual dengan media digital modern.

Untuk menemukan jawaban bagaimana komptensi guru Al-Qur'an Hadis dalam mengkolaborasikan antara media pembelajaran konvensional dengan media modern, penulis telah melakukan wawancara dengan beberapa orang guru. Salah seorang guru yang penulis wawancarai mengatakan bawha: pada dasarnya kami belum mampu menggunakan media modern dalam pembelajaran Al-Qur'an hadis terumata pada materi ilmu Tajwid, sehingga dengan adanya diklat ini, kami sangat terkesan dan dapat menambah wawasan kami bahwa ternyata dalam mencari dan menyelasaikan kasus dalam ilmu mawaris ada media khusus, sebagaimana dijelaskan yaitu aplikasi digital ilmu tajwid.

Kemudian penulis juga melihat langsung di lokasi penelitian tepatnya ketika berlangsungnya pembelajaran di Kelompok $\mathrm{C}$ bahwa ketika pembelajaran AlQur'an Hadis Materi Ilmu Tajwid berlangsung di dalam kelas ada persediaan LCD proyektor sebagai alat bantu, termasuk sebagian peserta telah mengggunakan aplikasi ilmu tajwid, hal ini mereka lakukan karna dalam proses. Namun, ada juga 
sebagian peserta menurut penulis amati mereka masih menggunakan buku, pulpen dan suarar peserta sendiri.

Dari hasil wawancara tersebut serta penulis observasi langsung di kelompok diskusi, dapat penulis simpulkan bahwa pada peserta diklat Al-Qur'an Hadis sudah menunjukkan kemajuan dalam mengkolaborasikan media pembelajaran manual dengan media aplikasi modern yaitu Aplikasi ilmu tajwid. Artinya sudah menggunakan media modrn sebagai alat bantu dalam pembelajaran Al-Qur'an Hadis yang berupa aplikasi ilmu Tajdwid, laptop, HP Android di samping juga media konvensional berupa buku, papan tulis, pulpen, kertas spidol, serta penghapus dalam pembelajaran di kelas.

Dalam hal ini, aplikasi adalah penggunaan dalam suatu komputer, instruksi (instruction) atau pernyataan (statement) yang disusun sedemikian rupa sehingga komputer dapat memproses input menjadi output. Aplikasi adalah kumpulan perintah program yang dibuat untuk melakukan pekerjaan tertentu (khusus). Aplikasi ilmu tajwid adalah sebuah aplikasi belajar ilmu tajwid yang memudahkan menguasai tajwid baik bagi guru maupun bagi peserta didik. Aplikasi ini dibuat untuk membantu umat Islam dalam belajar ilmu al-Qur'an.

Dalam pelaksanaan diklat Guru Madrasah Aliyah Di balai Diklat Keagamaan pada diklat Al-Qur'an Hadis ini, penulis mengarahkan kepada peserta diklat untuk menggunakan sebuah media modern yang sangat sederhana yaitu Aplikasi Android Tata Cara Belajar Baca Alquran/Tajwid. Dengan banyaknya teknologi yang semakin hari semakin canggih ini membuat banyak perubahan mulai dari cara manusia bertingkah laku didepan publik sampai pada cara pemecahan masalah dan masih banyak aspek kehidupan lainnya yang juga ikut berubah. Salah satunya adalah perubahan yang di alami umat islam adalah cara untuk mempelajari baca kitab suci alquran atau di namakan ilmu tajwid. Ilmu tajwid adalah ilmu yang mempelajari tata cara membaca AlQuran, yang sangat penting untuk di pelajari bagi seluruh umat islam. Walaupun dalam membaca Al-Qur'an yang baik dan benar tentu saja memerlukan pengajaran dan banyak dasar seperti pelafalan huruf yang baik dan benar serta panjang pendeknya suatu bacaan dalam Al-Qur'an dan masih banyak lagi.

Dan semua hal tersebut dalam meningkatkan kompetensi guru/peserta diklat Al-Qur'an Hadis penulis memberikan pemahaman dan menerapkan kepada mereka beberapa aplikasi ilmu tajwid. Beberapa perangkat dari Aplikasi ini adalah sebagai berikut:

\section{Aplikasi Mobile}

Istilah mobile mempunyai arti bergerak atau berpindah. Sehingga diperoleh pengertian bahwa aplikasi bergerak merupakan aplikasi yang dapat dijalankan walaupun pengguna bergerak atau berpindah. Dalam pemrograman aplikasi bergerak berbagai aspek teknis perangkat lebih menonjol karena memiliki banyak keterbatasan dibandingkan komputer konvensional atau PC. Kelebihan yang dimiliki perangkat mobile berupa akses keberbagai macam jaringan atau perangkat lainnya bisa membuat perangkat tersebut bisa dijadikan target utama serangan virus.

a. Tampilan Menu Utama

Gambar 2 merupakan tampilam dari menu utama pada aplikasi ilmu tajwid secara interaktif berbasis mobile yang merupakan halaman depan ketika pengguna 
pertama kali membuka aplikasi ini, menu utama aplikasi memiliki tiga buah button yaitu profil, masuk materi dan keluar.

b. Tampilan Menu Masuk Materi

Gambar 3 merupakan tampilan menu masuk materi, halaman ini ditampilkan kepada pengguna ketika pengguna memilih button masuk materi pada menu utama. Masuk materi ini ditampilkan dalam bentuk button yang terdiri atas tingkat awal, tingkat menengah, tingkat lanjut, serta exit Menu.

c. Tampilan Menu Tingkat Awal

Gambar 4 merupakan tampilan dari menu al jauf apabila button al jauf yang berada pada layout makharijul dan menu tingkat awal diklik. Pada menu al jauf ditampilkan materi al jauf disertai suara apabila gambar diklik, serta keluar menu.

d. Tampilan Menu Tingkat Menengah

Gambar 5 merupakan screen-shoot dari menu pembagian huruf hijaiyah apabila button pembagian huruf hijaiyah yang berada pada layout tingkat menengah diklik. Pada menu pembagian huruf hijaiyah ditampilkan materi pembagian huruf hijaiyah, serta Keluar Menu.

e. Tampilan Menu Tingkat Lanjut

Gambar 6 merupakan tampilan dari menu mad ashliy ketika button mad ashliy yang berada pada layout tingkat lanjut diklik maka ditampilkan materi mad ashliy serta suara apabila gambarnya diklik, serta Keluar Menu.

\section{Aplikasi Tajwid Lengkap Qt-Media}

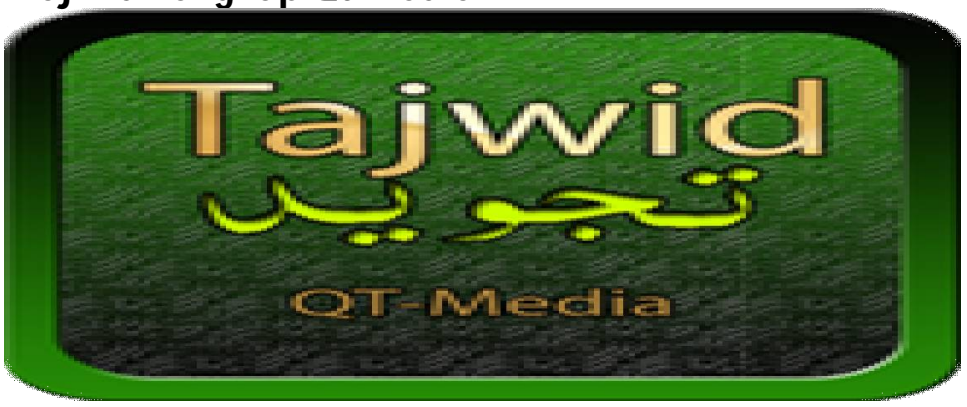

Gambar 1. Aplikasi Tajwid QT-Media
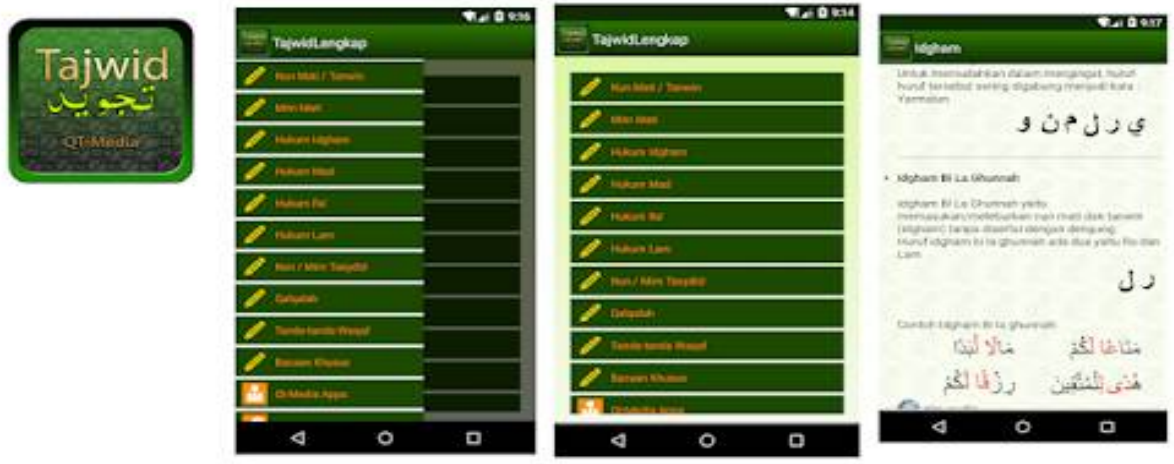

Gambar 2. Perangkat Aplikasi Tajwid QT-Media 


\begin{tabular}{|c|c|}
\hline aes & 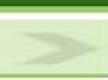 \\
\hline ales & $>$ \\
\hline a= & $>$ \\
\hline ase & $>$ \\
\hline 9 & $>$ \\
\hline प्रes & $>$ \\
\hline प्रि & $>$ \\
\hline aes & $>$ \\
\hline a $=$ & $>$ \\
\hline a= & $>$ \\
\hline
\end{tabular}

Gambar 3. Perangkat Materi
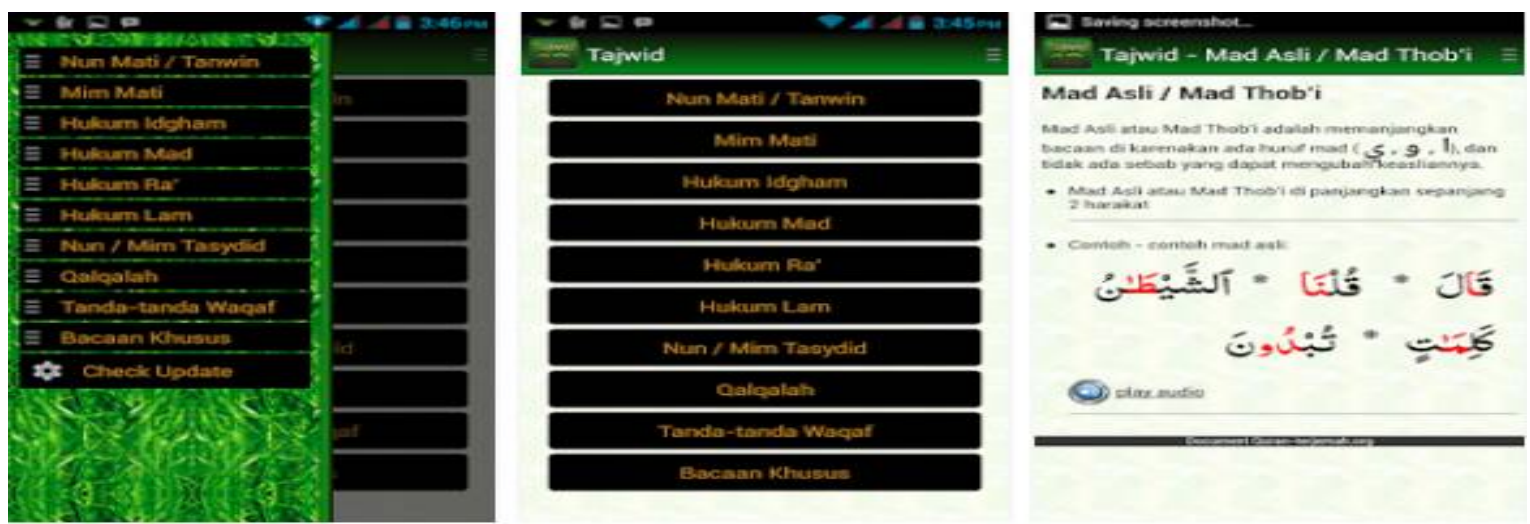

Gambar 4. Perangkat Materi

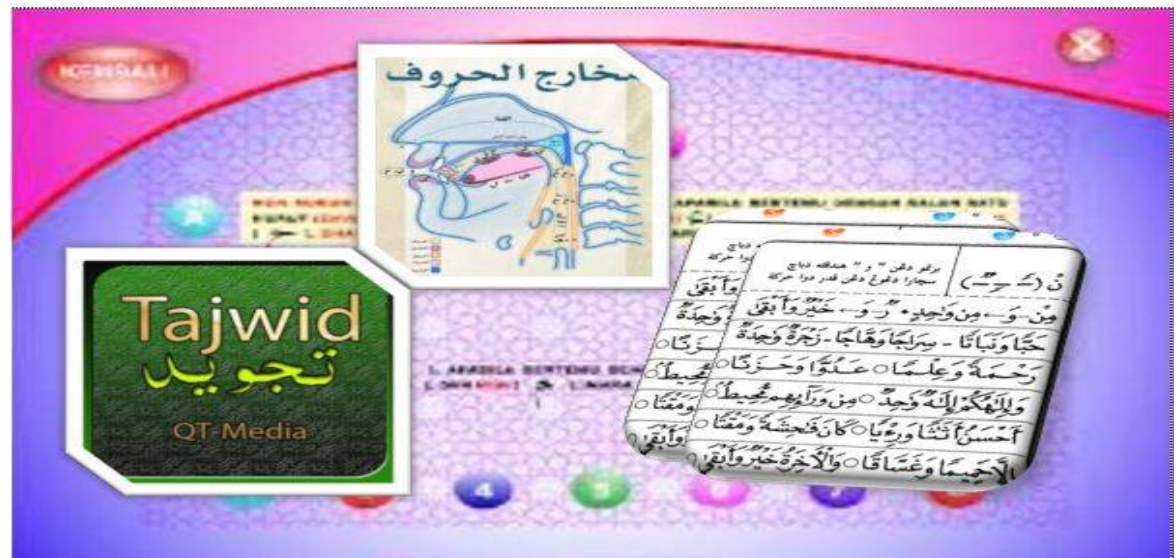

Gambar: 5 Makharijul Huruf 


\section{Penjabaran dari Tajwid Lengkap Qt-Media:}

a. Aplikasi Tajwid di lengkapi dengan contoh-contoh suaraAudion Ilmu tajwid adalah ilmu yang mempelajari tata cara membaca AlQuran, yang sangat penting untuk di pelajari bagi seluruh umat islam. Aplikasi ini dapat bekerja tanpa jaringan internet, Semoga bermanfaat,

b. Tajwid Lengkap Qt-Media 8.0 Memperbarui 2018-06-01

c. Update SDK

\section{Belajar Tajwid Lengkap dan Audio}

Belajar Tajwid Lengkap \& Audio adalah aplikasi Education yang dikembangkan oleh Ayiip. Kami hanya berbagi file APK asli. Anda dapat mendownload dan menginstal APK versi Belajar Tajwid Lengkap \& Audio terbaru dari link download langsung kami. Di halaman ini kami menyediakan file apk Belajar Tajwid Lengkap \& Audio 2.1 untuk Android 4.0 and up. Ini adalah aplikasi gratis yang terdaftar di kategori aplikasi Education. Gunakan tombol unduh di atas untuk mendownload APK ini. Pemasangan Aplikasi: $10000+$

Sekilas tentang Belajar Tajwid Lengkap dan Audio:

Penyedia : : Syarif Hidayat

Ukuran :28,4 MB

Kategori $\quad:$ Pendidikan

Kompatibilitas : Memerlukan iOS 10.3 atau versi lebih baru. Kompatibel dengan iPhone, iPad, dan iPod touch.

Bahasa

: Inggris

Batas Usia $\quad$ : Berperingkat 4+

Hak Cipta $\quad$ : (C) Ayiip Studio

Harga : Gratis

Berikut gambar dan perangkat Aplikasi Belajar Tajwid Lengkap dan Audio:

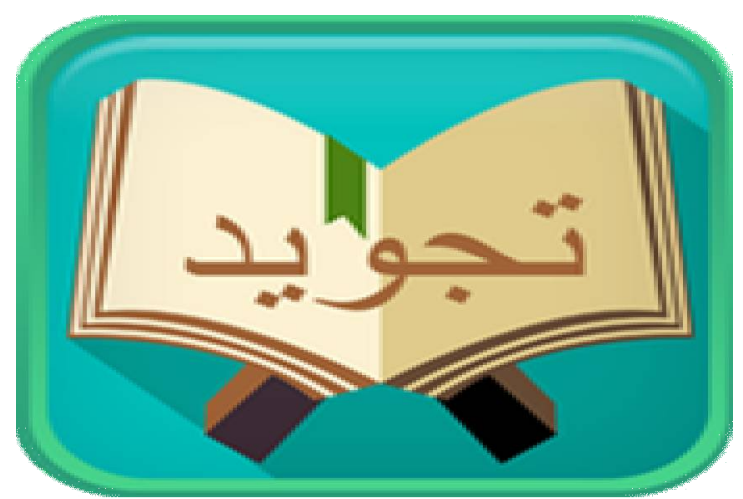

Gambar 6. Layar Pembuka Aplikasi Belajar Tajwid Lengkap dan Audio

Dalam Belajar Tajwid Lengkap dan Audio terdapat beberapa menu yang sangat memudahkan digunakan oleh siapa saja. Dalam pembelajaran Al-Qur'an bagi peserta diklat, penulis mengarahkan mereka satu persatu agar mampu menggunakannya dengan baik dalam proses pembelajaran di sekolah. Berikut daftar menu Belajar Tajwid Lengkap dan Audio: 


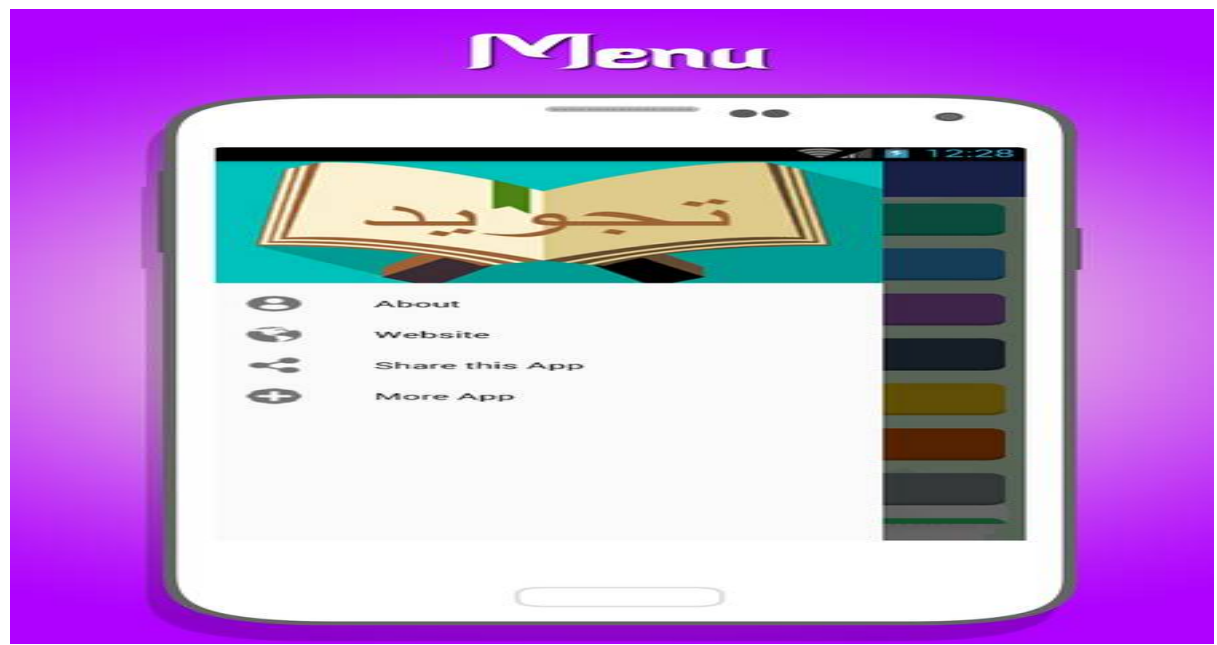

Gambar 7. layar Utama Aplikasi Belajar Tajwid Lengkap dan Audio

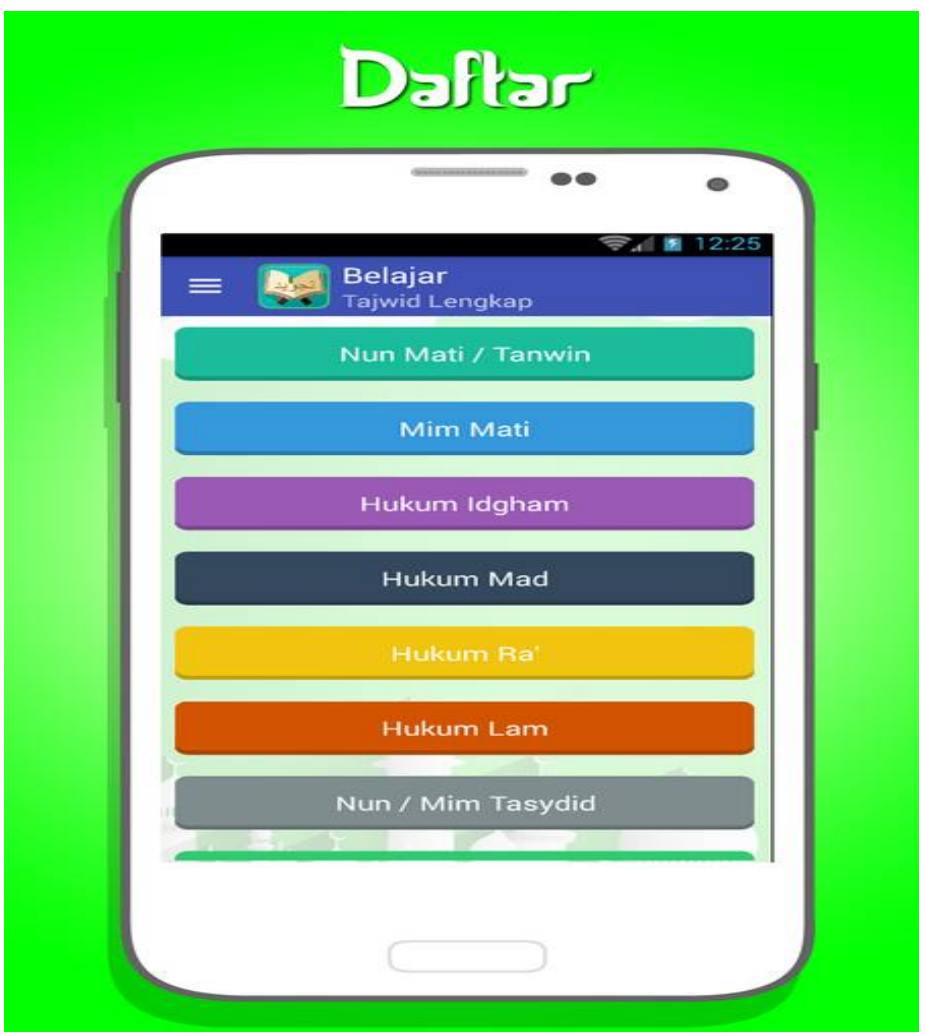

Gambar 8. Daftar menu 


\section{Daftar}

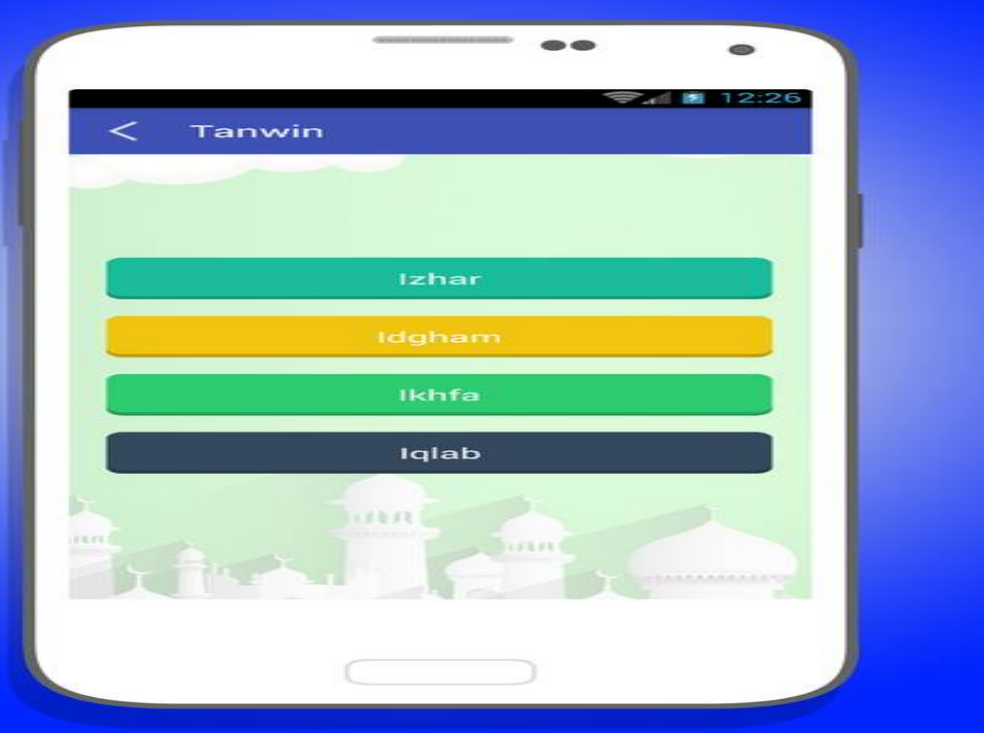

Gambar 9. Daftar Isi

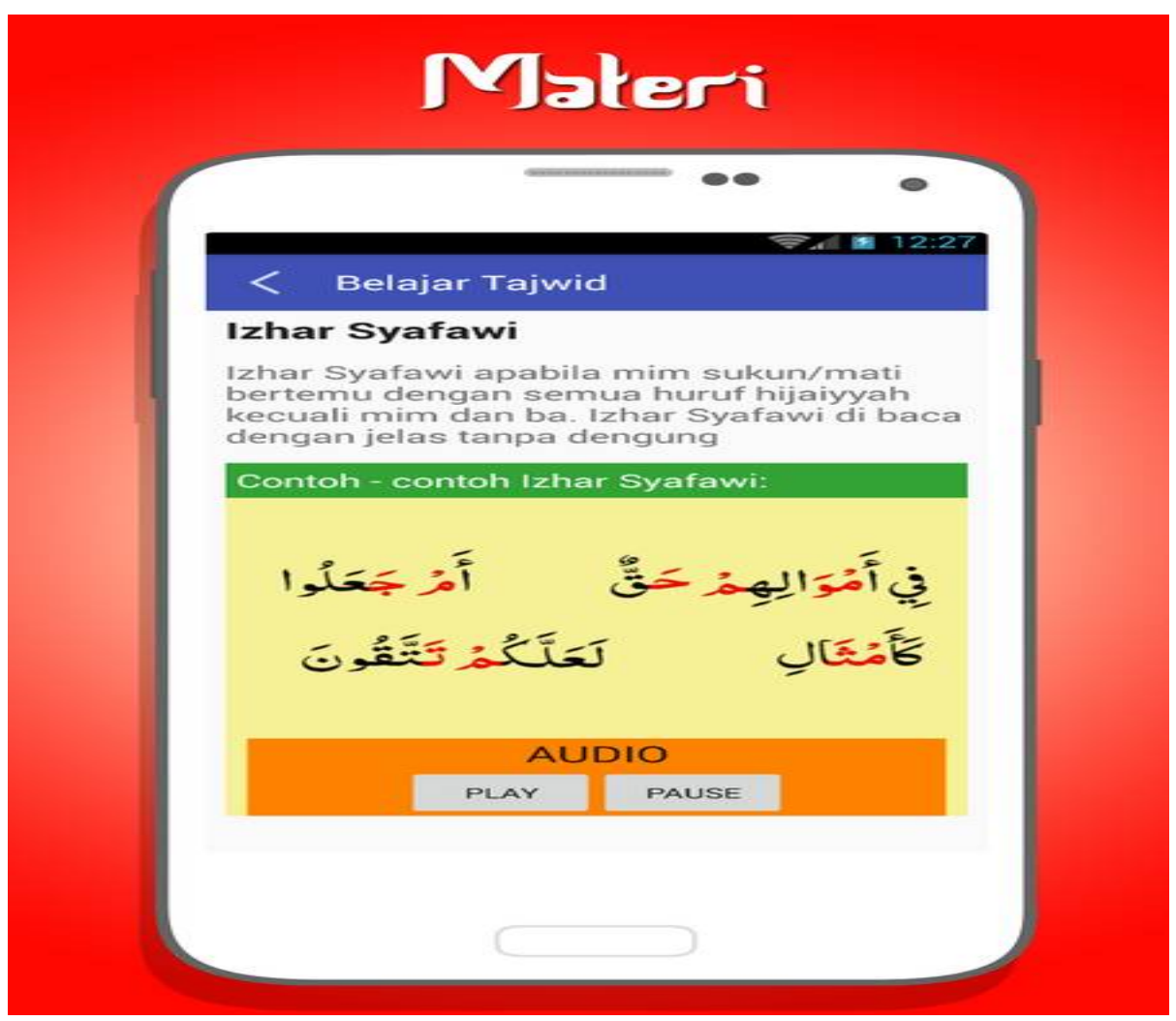

Gambar 10. Gambar Materi limu Tajwid 


\section{PEMBAHASAN}

\section{Komptensi Guru Al-Qur'an Hadis Dalam Menggunakan Media Pembelajaran}

Setelah penulis menganalisa secara mendalam berdasarkan hasil observasi penulis di lapangan penelitian dan juga wawancara penulis dengan beberapa orang guru tentang kompetensi mereka menggunakan media pembelajaran AlQur'an Hadis saat berlangsungnya proses pembelajaran di kelas adalah umumnya guru masih sangat minim pengetahuan mereka tentang media pembelajaran yang lebih memudahkan mereka dalam menyelesaikan kasus. Dalam artian bahwa ratarata mereka masih menggunakan media konvensional/digital seperti: Pulpen, Kertas, buku, papan tulis, spidol, penghapus.

Dengan demikian dapat penulis simpulkan bahwa menggunakan media pembelajaran sebagai alat bantu dalam proses pembelajaran Al-Qur'an hadis sangatlah penting dalam dunia pendidikan, baik pendidikan formal maupun non formal. Namun dalam menggunakan media tersebut diperlukan kompetensi dari dari guru, yang dalam hal ini adalah guru Al-Qur'an Hadis Madrasah Aliyah dan penyuluh Agama Islam Non PSN. Kompetensi Guru Al-Qur'an Hadis yang dirasa masih kurang dalam menggunakan media pembelajaran yang lebih modern perlu ditingkatkan lagi dengan belajar tekonologi atau ilmu pengetahuan dan teknologi.

\section{Upaya Peningkatan Kompetensi guru dalam mengkolaborasikan media Konvensional/manual dan media modern Aplikasi Ilmu Tajwid pada pembelajajaran Al-Qur'an Hadis}

Berdasarkan hasil wawancara dan observasi penulis terhadap peserta diklat Guru Madrasah Aliyah pada materi Ilmu tajwid dapat dijabarkan bahwa: kemampuan guru dalam mengkolaborasikan media Konvensional/manual dan media modern aplikasi ilmu tajwid pada pembelajajaran Al-Qur'an hadis masih minim, hal ini terlihat saat penulis memberikan suatu kegiatan pembelajaran dalam bentuk diskusi kelompok dengan memberikan beberapa soal kasus ternyata mereka belum mampu menggunakan aplikasi modern ilmu tajwid dengan baik. mengingat mereka rata-rata baru di bangku diklat ini menerima dan mempelajari media digital tersebut. Bahkan rata-rata mereka masih menggunkan media konvensional atau manual seperti buku, kertas, pulpen dan alat sederhana lainnya. Namun dalam pertemuan yang sama, setelah penulis menjelaskan keunggulan media modern Aplikasi digital ilmu tajwid dan tatacara penggunaan aplikasi tersebut sudah menunjukkan bahwa minat, semangat dan motivasi mereka semakin bersemangat dalam proses pembelajaran. Disamping itu, kompetensi merekajuga mengkat dengan menggunakan media modern tersebut.

Dalam pembelajaran Al-Qur'an hadis materi tajwid dengan peserta diklat, proses penggunnan media konvensional atau manual penulis kolaborasikan dengan media modern Aplikasi digital ilmu tajwid. Kadang-kadang penulis arahkan peserta menggunakan media manual saat berhadapan dengan soal yang ringan, tetapi saat berhadapan dengan soal yang sukar maka penulis arahkan peserta diklat menggunakan media modern Aplikasi digital ilmu tajwid penghitung ilmu mawaris. Hal ini bertujuan supaya peserta juga tidak boleh sama sekali melupakan media yang manual. 


\section{KESIMPULAN}

Kompetensi guru/peserta diklat dalam menggunakan media pembelajaran AlQur'an Hadis masih minim. Dalam proses pembelajaran di Balai Diklat Keagaam Aceh, rata-rata guru masih menggunakan media konvensional/digital seperti: Pulpen, Kertas, buku paket, papan tulis, spidol, penghapus. Sedangkan pemahaman mereka terhadap media modern aplikasi digital ilmu tajwid masih rendah, mengingat rata-rata usia peserta diklat telah memasuki usia 45 tahun ke atas sehingga penguasaan mereka terhadap dunia IT masih rendah.

Kemampuan guru dalam mengkolaborasikan media Konvensional/ manual dan media modern aplikasi ilmu tajwid pada pembelajajaran Al-Qur'an hadis masih rendah, hal ini terlihat saat penulis memberikan suatu kegiatan pembelajaran dalam bentuk diskusi kelompok ternyata mereka belum mampu menggunakan aplikasi ilmu tajwid dengan baik. mengingat mereka rata-rata baru di bangku diklat ini menerima dan mempelajari media digital tersebut. setelah penulis menjelaskan keunggulan media modern Aplikasi digital ilmu tajwid dan tatacara penggunaan aplikasi tersebut sudah menunjukkan bahwa minat, semangat dan motivasi mereka semakin bersemangat dalam menyelesaikan soal kasus ilmu mawaris. Disamping itu, kompetensi mereka juga mengkat dengan menggunakan media modern tersebut. Beberapa aplikasi yang penulis kenalkan kepada peserta diklat adalah Aplikasi Mobile, Aplikasi Tajwid Lengkap Qt-Media dan aplikasi Belajar Tajwid Lengkap dan Audio.

\section{DAFTAR PUSTAKA}

Alam A.L., Kahar D.M. 2013. Rancangan Bangun Aplikasi Pembelajaran Pengetahuan Umum untuk Pendidikan Anak Usia Dini Berbasis Android. Makassar: STMK Dipanegara Makassar.

Abdul Hadis \& Nurhayati. 2012. Manajemen Mutu Pendidikan, Bandung: Alfabeta.

Aditya Wahyudha Yunanta, Analisis Kompetensi Guru Dalam Menggunakan Media Pembelajaran PowerPoint pada Pembelajaran di SMK Negeri 6 Malang.

Aditiya Niarsa. 2013. Studi kompetensi guru dalam memanfaatkan mediapembelajaran berbasis teknologi informasi dan komunikasi (TIK) di SD NEGERI 01 Ledok Kecamatan Sambong Kabupaten Blora, Semarang: Fakultas Ilmu Pendidikan Universitas Negeri Semarang.

Cecep Kusnandi \& Bambang Sutjipto. 2011. Media Pembelajaran Manual dan Digital, Bogor: Galia Indonesia.

Cut Yusi Rahmita. 2017. Kompetensi Guru dalam Pemanfaatan Informasi dan Teknologi (IT) sebagai Media dalam Proses Pembelajaran di SMK Negeri 3 Banda Aceh, http:// etd.unsyiah.ac.id/index.php?p=show detail\&id=19586, Jurnal Ilmiah Pendidikan Guru Sekolah Dasar FKIP Unsyiah, 2 (2), 126- 134.

Dian Rosdiana. 2017. Pengaruh Kompetensi Guru Dan Komitmen Mengajar Terhadap Efektivitas Proses Pembelajaran Serta Implikasinya Pada Hasil Belajar Siswa Dalam Mata Pelajaran Ekonomi, Jurnal Penelitian 
Pendidikan is issued by Lembaga Penelitian dan Pengabdian Kepada Masyarakat (LPPM) Universitas Pendidikan Indonesia, ISSN: p.1412-565X e.2541-4135

Darmawiyah. 2017. Strategi Pembelajaran Fiqih Mawaris Pada Dayah Madinatuddiniyah Darul Huda Aloh Gadeng Dan Dayah Terpadu Madinatuddiniyah Jabal Nur Paloh Lada Di Kabupaten Aceh Utara. Jurnal Ilmiah Didaktika, 17 (2), 245-263.

E. Mulyasa. 2013. Standar Kompetensi dan Sertifikasi Guru. Bandung: Remaja Rosdakarya.

Helme Fajar Nurmeina, 2017. Media Pembelajaran Modern, https:// civitas.uns.ac.id/helminurmeina/2017/05/03/mediapembelajaran-modern/

Husain, Chaidar. 2014. Pemanfaatan Teknologi Informasi dan Komunikasi dalam Pembelajaran di SMA Muhammadiyah Tarakan. Jurnal Kebijakan dan Pengembangan Pendidikan, 2 (2).

Jejen Musfah. 2015. Peningkatan Kompetensi Guru: Melalui Pelatihan dan Sumber Belajar Teori dan Praktik, Jakarta: Kencana.

Kunandar. 2009. Guru Profesional: Implementasi Kurikulum TingkatSatuan Pendidikan (KTSP) dan Sukses dalam Sertifikasi Guru, Jakarta: RajaWali Pers.

Lestari, Rajefi Ambar. 2016. Kompetensi guru dalam menggunakan media dalam meningkatkan mutu pembelajaran di MI Miftahul Huda Kangkung Mranggen Demak

Musfah, Jejen. 2015. Peningkatan Kompetensi Guru melalui Pelatihan dan Sumber Belajar Teori dan Praktik. Jakarta: Prenadamedia Group.

M.Ramli. 2015. Media Pembelajaran dalam Perspektif Al Qur'an dan Hadits Ittihad. Jurnal Kopertais Wilayah XI Kalimantan, XIII (I), April/ 2015), 133-135.

Niken Krysdianawati. 2012. Hubungan Kompetensi Guru dan Efektifitas Penggunaan Media Pembelajaran Terhadap Prestasi Belajar di Bidang TIKSMKN Se-Kabupaten Ponorog. Malang: Prodi Pendidikan Teknik Informatika, Jurusan Teknik Elektro Universitas Negeri Malang.

Nana Sudjana \& Ahmad Rivai. 2007. Media Pengajaran, Bandung: Sinar Baru Algesindo.

N Krysdianawati. 2012. Hubungan Kompetensi Guru dan Efektifitas Penggunaan Media Pembelajaran Terhadap Prestasi Belajar di Bidang TIK SMKN SeKabupaten Ponorogo.

Republik Indonesia. 2005. Undang-undang No. 14 Tahun 2005 tentang Guru dan Dosen. Sekretariat Negara. Jakarta.

Risa Putri Wulandari. 2014. Pembelajaran Tradisional (Tradisional learning), https:/ / blogspot.com/ 2014/ 11/ pembelajaran-tradisional-trasitional.html 
Rinu Larasati. 2017. Media Pembelajaran, https:/ / civitas.uns.ac.id/ rinularasati/ tag/ media-pembelajarankonvensional-dan-modern/

Siswoyo, Dwi. 2013. Ilmu Pendidikan. Yogyakarta: UNY Press.

Yusrizal, Intan Safiah, Nurhaidah. 2017. Kompetensi Guru Dalam Memanfaatkan Mediapembelajaran Berbasis Teknologi Informasi Dan Komunikasi (TIK) Di SD Negeri 16 Banda Aceh. Jurnal Ilmiah Pendidikan Guru Sekolah Dasar FKIP Unsyiah, 2 (2),126-134.

Ziyad Fauzi Ahmad. 2017. Pengembangan Multimedia Interaktif Mawaris Untuk Mata Pelajaran Agama Islam Kelas XII Di SMA Islam Terpadu Abu Bakar Yogyakarta. E-Jurnal Program Studi Teknologi Pendidikan, 6 (6). 